\title{
SETD1B Gene
}

National Cancer Institute

\section{Source}

National Cancer Institute. SETD1B Gene. NCI Thesaurus. Code C142221.

This gene is involved in post-translational methylation of the lysine at position 4 in histone $\mathrm{H} 3$. 